\title{
Pemidanaan Terhadap Pelaku Homoseksual ditinjau dari Perspektif Hak Asasi Manusia di Indonesia
}

\author{
Chairul Azmi ${ }^{1}$, Rusydi Ali Muhammad², Rizanizarli ${ }^{3}$ \\ ${ }^{1}$ Program Studi Magister Ilmu Hukum, Fakultas Hukum Universitas Syiah Kuala, \\ E-mail: chrul_azmi@yahoo.co.id \\ ${ }^{2}$ Fakultas Syariah dan Hukum Universitas Islam Negeri Ar-Raniry, \\ E-mail: rusdialimuha52@gmail.com \\ ${ }^{3}$ Fakultas Hukum Universitas Syiah Kuala, E-mail: riza_nizarli@yahoo.com
}

\begin{abstract}
Info Artikel
Masuk: 25 April 2019

Diterima: 21 Januari 2020

Terbit: 31 Mei 2020

Keywords:

Punishment; Homosexual;

Human Rights

Kata kunci:

Pemidanaan; Homoseksual;

Hak Asasi Manusia

Corresponding Author:

Chairul Azmi, E-mail:

chrul_azmi@yahoo.co.id

DOI:

10.24843/JMHU.2020.v09.i0

1.p04
\end{abstract}

\begin{abstract}
Indonesia unless the province of Aceh does not prohibit homosexual acts absolutely and does not legalize same-sex marriage. From 2016 statistical data, it is known that the number of homosexuals in Indonesia was 10-20 million. Human rights universalism has always been a reason when Eastern cultures differ from Western cultures. In the theory of human rights, in addition to the theories universalism of human rights, there is another known as human rights relativism. Western cultures that do not look bad behavior of homosexuality should not be forced into the eastern culture. Similarly, eastern cultures should also not be used as catalysts to measure Western culture politeness. The research aims to determine the adherence to homosexuals can be categorized as human rights violations in Indonesia. The research is a normative juridical study. The data used consists of primary, secondary, and tertiary legal substances. Based on the results of the research known that if in the future the pipetting against male/female homosexual adults who like to be applied in Indonesia, they are not violations of human rights. This is a consequence of CAT article 1 which essentially states that the law-based torture is excluded from human rights violations.
\end{abstract}

\begin{tabular}{l} 
Abstrak \\
\hline Indonesia kecuali provinsi Aceh tidak melarang perbuatan \\
homoseksual secara mutlak dan tidak pula melegalkan pernikahan \\
sesama jenis. Dari data statistik tahun 2016 dapat diketahui \\
bahwa jumlah kaum homoseksual di Indonesia mencapai 10-20 \\
juta jiwa. Universalisme HAM selalu dijadikan alasan ketika \\
budaya timur berbeda dengan budaya barat. Padahal dalam teori- \\
teori HAM yang dikemukakan para ahli, selain teori \\
universalisme HAM masih ada lagi yang disebut dengan \\
relativisme HAM. Budaya barat yang tidak memandang buruk \\
perilaku homoseksualitas seharusnya tidak dipaksakan untuk \\
masuk ke dalam budaya timur. Begitu juga budaya timur \\
sebaiknya juga tidak dijadikan katalisator untuk mengukur \\
kesopanan budaya barat. Penelitian ini bertujuan untuk \\
mengetahui pemidanaan terhadap pelaku homoseksual dapat \\
dikategorikan sebagai pelanggaran HAM di Indonesia. Penelitian \\
ini merupakan penelitian yuridis normatif. Data yang digunakan \\
terdiri bahan hukum primer, sekunder dan tersier. Berdasarkan
\end{tabular}


hasil penelitian diketahui bahwa jika di masa yang akan datang pemidanaan terhadap laki-laki/wanita dewasa homoseksual yang suka sama suka diterapkan di Indonesia, semuanya bukanlah merupakan pelanggaran HAM. Hal ini merupakan konsekuensi dari Pasal 1 CAT yang pada intinya menyatakan bahwa pemidanaan/penyiksaan yang berdasarkan hukum dikecualikan dari pelanggaran HAM.

\section{Pendahuluan}

Tuhan menciptakan manusia berpasang-pasangan. Penciptaan laki-laki dan perempuan diikuti dengan pemberian hasrat seksual. Ketika laki-laki dan perempuan saling mengenal, selalu ada kecenderungan untuk melakukan hubungan seksual. Ada yang melakukannya dengan prosedur yang legal, dan ada pula yang melakukannya dengan prosedur yang ilegal. Pemberian elemen ini merupakan suatu anugerah dari Tuhan karena hubungan seksual itu sendiri bertujuan untuk mendapatkan kenikmatan. Selain itu, adanya hubungan seksual juga merupakan cara Tuhan agar manusia tetap ada dan berkembang biak di muka bumi.

Fitrah hubungan seksual sebagaimana dijelaskan di atas ternyata tidak selalu demikian adanya. Ada manusia yang memiliki kecenderungan melakukan hubungan seksual dengan jenis kelamin yang sama, baik itu laki-laki dengan laki-laki maupun perempuan dengan perempuan. Perilaku semacam ini biasa disebut dengan homoseksual. Laki-laki yang mempunyai kecenderungan homoseksual sering disebut gay, sedangkan perempuan disebut lesbian.

Perilaku Homoseksual yang terjadi dewasa ini bukanlah hal yang baru. Al-Qur'an menceritakan kepada kita bahwa kaum Nabi Luth adalah manusia-manusia yang pertama kali melakukan praktik homoseksual. ${ }^{1}$ Kemudian kaum ini dibinasakan oleh Allah dengan hujan batu. ${ }^{2}$ Selepas peristiwa itu ternyata kecenderungan hubungan seksual sesama jenis tidak serta merta hilang, namun masih tetap ada.

Negara-negara di dunia tidaklah melihat homoseksualitas dalam satu visi yang sama. Negara Arab cenderung mengatur perbuatan tersebut sebagai tindak pidana. ${ }^{3}$ Negara barat cenderung tidak melarang perbuatan tersebut. Fenomena LGBT di dunia ditemukan pada sekitar abad ke 19, pada masa itu menurut American Psychiatric assosiation (APA) LGBT di anggap sebagai gangguan mental. Menurut Statistik Manual of Mental Health (DSM) tahun 1952 menganggap bahwa LGBT sebagai gangguan kepribadian. Oleh karena itu seiring berjalannya waktu para pelaku LGBT mengalami deskriminasi dari masyarakat sehingga pada tahun 1950-1970 para pendukung LGBT menciptakan gerakan penolakan terhadap diskriminasi LGBT. Hal ini membuat DSM pada tahun 1968 menghapuskan LGBT dari daftar gangguan mental. Dan pada tahun 1973 APA juga menyatakan bahwa LGBT bukan penyakit mental namun hanya perilaku yang biasa. Berdasarkan fakta yang diperoleh, APA mengubah pernyataannya terdahulu yang menganggap LGBT sebagai gangguan mental menjadi

${ }^{1}$ QS. Al-A'raf ayat 80.

2 QS. As-Syu'ara ayat 173.

3 Newsokezone.com. Polisi Arab Saudi Gerebek Pesta Gay di Jeddah. http://news.okezone.com/read/2015/06/16/18/1166042/polisi-arab-saudi-gerebek-pestagay-di-jeddah 
perilaku yang biasa disebabkan karena banyaknya para pendukung LGBT yang memprotes konvensi tersebut, yang membuat APA tidak nyaman dengan hal tersebut. ${ }^{4}$ Hal ini membuat kaum homoseksual beruforia dan semakin gencar dalam mengkampanyekan perilaku homoseksualnya.

Belanda adalah negara pertama yang mengakui pernikahan sejenis. selanjutnya pada tanggal 26 Juni 2015 MA Amerika Serikat mengesahkan aturan terkait legalisasi terhadap pernikahan sejenis. Dengan disahkannya aturan tersebut membuat para pendukung LGBT di berbagai negara bereuforia tanpa terkecuali di Indonesia. ${ }^{5}$ Indonesia tidak melarang perbuatan ini secara mutlak dan tidak pula melegalkan pernikahan sesama jenis. Data statistik tahun 2016 menunjukkan jumlah kaum homoseksual di Indonesia mencapai 10-20 juta jiwa. Populasi kaum homoseksual yang semakin meningkat disebabkan adanya fenomena pergeseran pandangan masyarakat terhadap homoseksual. 6 Pergeseran pandangan tersebut merupakan hasil dari promosi gencar kegiatan-kegiatan yang berbau homoseksualitas yang tak jarang terjadi di beberapa kota besar. Kaum homoseksual di Indonesia mempromosikan kegiatankegiatan terkait homoseksualiatas tersebut dengan dalih kebebasan berekspresi yang merupakan salah satu hak asasi manusia.

Kegiatan promosi homoseksual berlangsung secara gencar di seluruh wilayah Indonesia kecuali Provinsi Aceh. Di Provinsi ini, perilaku homoseksual diancam dengan pidana cambuk maksimal seratus (100) kali, atau denda paling banyak 1.000 (seribu) gram emas murni atau penjara paling lama 100 (seratus) bulan. ${ }^{7}$ Ancaman pidana yang begitu mengerikan tersebut ternyata tidak dihiraukan ketika hasrat seksual terhadap sesama jenis sudah menuntut untuk dipuaskan. Selasa 28 maret 2017 sekitar pukul 23.30 WIB warga menangkap dua pemuda yang diduga pasangan homoseksual di salah satu rumah kos di wilayah Rukoh, Kecamatan Syiah Kuala, kota Banda Aceh. ${ }^{8}$

Setelah kejadian penangkapan tersebut, Deputi Direktur Divisi Asia pada Human Rights Watch mengecam keras tindakan warga yang menangkap pasangan homoseksual tersebut dan mengecam pidana yang diancamkan oleh Pemerintah Aceh. ${ }^{9}$ Lebih lanjut lagi Direktur Kampanye Amnesty International untuk Asia Tenggara, Josef Benedict menyatakan bahwa hukuman yang dilakukan terhadap

4 Santoso Budiarti Meilanny, LGBT dalam Perspektif Hak Asasi Manusia, Social Work Jurnal, Vol. 6, No. 2, h. 154-272.

5 Thisisgender.com. (2016) Sejarah Homoseksual: Penyimpangan yang Melintas Zaman. https://thisisgender.com/sejarah-homoseksual-penyimpangan-yang-melintas-zaman/

6 Tribunnews.com. (2016). Kamerad Prihatin Kaum Homoseksual di Indonesia Kian Memperlihatkan Eksistensinya. https://www.tribunnews.com/metropolitan/2016/09/23/kamerad-prihatin-kaumhomoseksual-di-indonesia-kian-memperlihatkan-eksistensinya

7 Pasal 63 ayat (1) dan 64 ayat (1) Qanun Aceh Nomor 6 Tahun 2014 Tentang Hukum Jinayat (Selanjutnya disebut Qanun Jinayat).

8 Tribunnews.com. (2016). Warga Rukoh Tangkap Pasangan Homoseksual, saat Digerebek Keduanya Sedang Tanpa Busana. https://www.tribunnews.com/regional/2017/03/29/warga-rukoh-tangkap-pasanganhomoseksual-saat-digerebek-keduanya-sedang-tanpa-busana

${ }_{9}$ Go-Batam. berita maraknya kaum lgbt di indonesia pasangan homoseksual tertangkap warga sedang mesum di indekos. thttps://go-batam.co/berita-maraknya-kaum-lgbt-di-indonesiapasangan homoseksual tertangkap-warga-sedang-mesum-di-indekost.html 
pelaku hubungan seks secara suka sama suka dengan hukuman cambuk 100 kali adalah sesuatu perbuatan tidak terpuji dan merupakan suatu pelanggaran terhadap HAM, oleh karena itu aturan semacam ini harus segera dicabut. ${ }^{10}$

Universalisme HAM selalu dijadikan alasan ketika budaya timur berbeda dengan budaya barat. Padahal dalam teori-teori HAM yang dikemukakan para ahli, selain teori universalisme HAM masih ada lagi yang disebut dengan relativisme HAM. Budaya barat yang tidak memandang buruk perilaku homoseksualitas seharusnya tidak dipaksakan untuk masuk ke dalam budaya timur. Begitu juga budaya timur sebaiknya juga tidak dijadikan katalisator untuk mengukur kesopanan budaya barat. Pemaksaan paradigma mengenai hak asasi manusia hanya akan menghasilkan perdebatan yang tak berujung.

Berdasarkan uraian latar belakang di atas, Penulis tertarik untuk mengkaji tentang pemidanaan pelaku homoseksual dalam perspektif hak asasi manusia di Indonesia untuk menjawab tiga permasalahan berikut: Pertama, Apakah pemidanaan terhadap suatu perbuatan oleh suatu negara dimana perbuatan tersebut tidak dipidana di negara lain dapat dibenarkan berdasarkan perspektif HAM? Kedua, Apakah pelaku homoseksual layak dijatuhi pidana? Ketiga, Apakah pemidanaan terhadap pelaku homoseksual dapat dikategorikan sebagai pelanggaran HAM?

\section{Metode Penelitian}

Metode penelitian yang digunakan dalam penelitian ini adalah yuridis normatif yaitu dengan menganalisis aspek hukum pidana dan aspek HAM terkait pemidanaan terhadap pelaku homoseksual. Bahan yang digunakan terdiri dari bahan hukum primer, sekunder dan tersier. Pendekatan yang digunakan terdiri dari pendekatan peraturan perundang-undangan (statuta approach), pendekatan historis (historical approach), dan pendekatan sosiologis (sociological approach). Bahan hukum yang telah dikumpulkan kemudian dianalisa secara kualitatif dengan teori Tujuan Pemidanaan dan teori Dasar Pemidanaan sebagai teori yang mewakili aspek hukum pidana, serta teori Relativisme HAM yang mewakili aspek HAM.

\section{Hasil dan Pembahasan}

\subsection{Pemidanaan dalam Perspektif HAM}

Pemidanaan pada dasarnya merupakan pelanggaran HAM karena merupakan penyiksaan terhadap manusia. Tetapi dalam konteks penerapan hukum suatu negara, pemidanaan dianggap tidak melanggar HAM. Dasarnya adalah:

For the purposes of this Convention, the term "torture" means any act by which severe pain or suffering, whether physical or mental, is intentionally inflicted on a person for such purposes as obtaining from him or a third person information or a confession, punishing him for an act he or a third person has committed or is suspected of having committed, or intimidating or coercing him or a third person, or for any reason based on discrimination of any kind, when such pain or

10 Riau Online. (2015). 100 Cambuk bagi Pelaku Zina dan Homoseksual di Aceh. https:// www.riauonline.co.id/nasional/read/2015/10/26/100-cambuk-bagi-pelaku-zinadan-homoseksual-di-aceh 
suffering is inflicted by or at the instigation of or with the consent or acquiescence of a public official or other person acting in an official capacity. It does not include pain or suffering arising only from, inherent in or incidental to lawful sanctions. ${ }^{11}$

Pembenaran pidana berdasarkan hukum terdapat pada kalimat terakhir aturan tersebut yaitu "Hal itu (penyiksaan) tidak meliputi rasa sakit atau penderitaan yang semata-mata timbul dari, melekat pada, atau diakibatkan oleh suatu sanksi hukum yang berlaku".

Ilmu hukum pidana mengenal pembagian delik yaitu delik undang-undang dan delik hukum. Delik hukum adalah perbuatan yang pasti dipandang buruk oleh siapapun, kapan pun, dan dimana pun walaupun tidak diatur secara tertulis dalam aturan perundang-undangan. Contohnya pencurian, pembunuhan, penganiayaan, pemerkosaan, dll. Sedangkan delik undang-undang adalah perbuatan yang dikategorikan perbuatan yang buruk karena dikategorikan demikian dan diancamkan pidana kepada pelakunya oleh penguasa.

Delik undang-undang tersebut bisa berbeda antara setiap negara. Sebagai contoh, di Indonesia setiap kendaraan yang berada di jalan raya wajib berjalan di jalur kiri, ketika ada pengendara kendaraan bermotor yang berjalan di jalur kanan (melawan arus) maka ia bisa dikenakan pidana. Di Amerika malah sebaliknya, kendaraan bermotor harus berjalan di jalur kanan. Jika ada kendaraan yang berjalan di jalur kiri maka pengendaranya bisa dikenakan pidana. Jika kita lihat berdasarkan perspektif universalisme HAM maka Indonesia dan Amerika bisa masuk kategori pelanggar Pasal 13 ayat (1) DUHAM apabila pasal tersebut ditafsirkan secara letterlijk yaitu : Everyone has the right to freedom of movement and residence within the borders of each state (Setiap orang berhak atas kebebasan bergerak dan berdiam di dalam batas-batas setiap negara). Apa artinya DUHAM jika setiap negara di dunia masuk kategori pelanggarnya?

Dalam contoh di atas biasanya Amerika akan menjadikan dalih relativisme HAM sebagai justifikasi pembatasan hak kebebasan bergerak yang diterapkan berbeda antara satu negara dengan negara lainnya. Lain halnya jika yang menjadi pokok pembahasan adalah kerelatifan hak asasi manusia di bidang seksualitas. Negaranegara barat akan mengatakan bahwa pemidanaan terhadap homoseksual adalah melanggar HAM dengan dalih universalisme HAM. Standar ganda ini tak ubahnya seperti orang yang mengharamkan kambing bagi orang lain karena dia benci tetapi menghalalkan anjing bagi orang lain karena dia suka.

Di dunia internasional, produk HAM diyakini dengan cara promosi bahwa HAM dapat menguntungkan semua pihak. Padahal para promotor HAM ketika berusaha melindungi masyarakat dari suatu pelanggaran, mereka melakukan pengkhianatan dan pelanggaran yang lain yaitu dominasi kebudayaan dan menindas hak budaya orang lain. ${ }^{12}$ Pengkhianatan dan pelanggaran para promotor HAM tersebut kiranya dapat dijadikan alasan untuk tetap menerapkan nilai-nilai HAM berdasarkan pemahaman budaya lokal. Pengikutan terhadap universalisme HAM sebagaimana yang dipromosikan para pengkhianat dan pelanggar tersebut merupakan suatu kebodohan yang naif.

11 Article 1 paragraph 1 Convention Againts Torture and Other Cruel, Inhuman or Degrading Treatment or Punishment. (Selanjutnya disebut CAT).

12 Zeffry Alkatiri, Belajar Memahami HAM, Ruas, Depok, 2010, h. 77. 
Declaration Universal of Human Rights (DUHAM) merupakan teks yang menetapkan standar umum yang berkaitan dengan hubungan antara warga negara dan negara, dan penghormatan terhadap hak asasi manusia. ${ }^{13}$ Jika DUHAM (berlaku universal) merupakan standar umum, maka analogi acontrarionya adalah undang-undang nasional suatu negara (berlaku parsial) menempati posisi standar khusus. Oleh karena itu negara berhak untuk menentukan sendiri bagaimana standar-standar tersebut dibentuk dalam hukum positif sesuai dengan budaya yang berlaku di masyarakatnya.

\subsection{Homoseksualitas dan Bahayanya}

Homoseksual ialah suatu ketertarikan seksual terhadap individu dengan jenis kelamin yang sejenis. Gay atau lesbian merupakan istilah lain perilaku homoseksual masingmasing pada laki-laki dan perempuan. ${ }^{14}$ Ketertarikan di sini adalah hasrat seseorang dalam melakukan hubungan seksual terhadap laki-laki atau perempuan. ${ }^{15}$

Homoseksualitas bukan merupakan hal baru. Banyak literatur yang mengulas aktivitas ini di berbagai tempat dari masa ke masa. Hampir setiap suku, bangsa dan kerajaan sejak zaman Mesir Kuno sampai sekarang memiliki cerita dan istilah tersendiri dalam menggambarkan kebiasaan ini. Kaum Sodom merupakan kaum yang pertama kali melakukan perbuatan homoseksual lebih kurang sekitar 4215 tahun yang lalu, hal ini dapat di telusuri dari berbagai kitab suci baik di dalam Al-Quran (Islam) maupun Injil (Kristen). ${ }^{16}$ Dalam ajaran Kristen sebenarnya juga telah dinyatakan bahwa sodomi merupakan suatu pelanggaran hukum Tuhan. Perilaku homoseksual banyak terjadi pada zaman Yunani Kuno. ${ }^{17}$ Plato $(427-347 \mathrm{M})$ dalam diskusinya yang berjudul Symposium diceritakan pada masa itu ada pesta minuman khusus pria. Tema dialongnya adalah tentang perilaku homoseksual. ${ }^{18}$ Kebanyakan dari kaisar Romawi memilih pasangan lelakinya. Akan tetapi pada 6 Agustus 390 M Kaisar Kristen Theodosius mengkriminalisasi dan mengutuk pasangan homoseksual dengan cara di bakar di tiang. ${ }^{19}$

Penerimaan masyarakat terhadap perilaku seksual juga berbeda-beda dari zaman ke zaman. Berdasarkan sejarah pada zaman pra industri $41 \%$ dari 42 budaya menolak terhadap perilaku Homoseksual, yang menerima dan/atau acuh terhadap homoseksual sebesar $21 \%$, dan sisanya tidak memiliki konsep tentang homoseksual. Dari data yang di kumpulkan oleh para ahli sejarah dilaporkan bahwa sekitar 59\% homoseksual tidak ada atau jarang pada masa itu, dan sekitar $41 \%$ menganggap

${ }^{13}$ Antonio Cassese, Hak Asasi Manusia di Dunia yang Berubah, Yayasan Obor Indonesia, Jakarta, Oktober 2005, h. 67.

${ }^{14}$ Feldmen, R. S, Understanding Psychology, Mc Graw-Hill Publishing Company , Second Edition, New York, 1990, h. 359.

15 Nietzel, dkk, Abnormal Psychology, Allyn dan Bacon.Inc., Boston, 1998 h. 489.

16 Syed Muhammad Naquib Al-Attas, On Justice and the Nature of Man, IBFIM, Kuala Lumpur, 2015, h. 57.

17 Plato, Laws, Book VIII, Penguin Books, 1972, h. 340.

18 Brent L. Pickett, The Historical Dictionary of Homosexuality, The Scarecrow press, Marryland, 2009, h.. 10-13 \& 153-154

${ }^{19}$ Guido Ruggiero, The Boundaries of Eros: Sex crime and Sexuality in Renaissance Venice, Oxford University Press, London, 1985, h. 201-203. 
homoseksual di anggap biasa. ${ }^{20}$ Salah satu sikap penolakan dapat dilihat pada zaman Yunani Kuno tepatnya di Kota Athena, pada masa itu terhadap pelaku homoseksual diberikan hukuman yang tegas. Untuk pelaku homoseksual dilarang untuk menduduki posisi-posisi penting di masyarakat dan dibatasi ruang geraknya dalam kehidupan sosial. Di sisi lain terdapat juga toleransi yang begitu kuat terhadap kaum homoseksual, seperti yang terjadi di Kota Pompey pada zaman Romawi Kuno. ${ }^{21}$

Ada beberapa hal yang menjadi penyebab homoseksualitas. Ditinjau dari pendekatan biologi bahwa perkembangan homoseksual dipengaruhi oleh faktor genetik. Kondisi ini dipengaruhi oleh ibu yang terlalu melindungi sedangkan ayah cenderung pasif. Pengalaman juga menjadi salah satu faktor seseorang menjadi homo. Dan dari beberapa penelitian juga dinyatakan homoseksual bisa timbul dikarenakan pada masa kanak-kanak mengalami pelecehan seksual. ${ }^{22}$ Senada dengan itu Paul Cameron Ph.D dari Family Research Institute dalam penelitiannya menyatakan bahwa dorongan untuk melakukan homosesksual disebabkan karena pernah di sodomi waktu masih kecil dan faktor lingkungan. ${ }^{23}$

Hingga saat ini belum ada literatur yang menyebutkan bahwa kebiasaan homoseksual ini muncul akibat kurangnya jumlah perempuan. Pada tahun 2012, data dari Bank Dunia memperlihatkan jumlah laki-laki dan perempuan yang dikumpulkan dari semua negara di dunia hampir mendekati jumlah yang sama atau lebih tepatnya dinyatakan dengan perbandingan $1: 1,01$. Hal yang sama juga dijumpai di negaranegara yang mengizinkan hubungan sesama jenis, seperti Belanda, Belgia, Kanada, Amerika Serikat. Perbandingan jumlah laki-laki dan perempuan di negara-negara tersebut juga tidak berbeda secara signifikan. Rasio laki-laki dibandingkan perempuan di negara-negara tersebut masing-masing 0,$98 ; 0,96 ; 0,98 ; 0,97$. Berdasarkan data tersebut, di keempat negara yang disebutkan di atas dijumpai bahwa jumlah wanita lebih banyak dari laki-laki. ${ }^{24}$

Perbuatan yang dianggap sumber kenikmatan oleh beberapa orang ini bukan tanpa bahaya dan resiko terutama jika ditinjau dari sudut pandang ilmu kedokteran. Memang pada tahun 1973, Asosiasi Psikiatri Amerika telah menghapus homoseksualitas dalam daftar penyakit mental. Hal ini juga diamini oleh Organisasi Kesehatan Dunia (WHO) dalam kebijakannya sehingga saat ini homoseksual tidak dianggap sebagai sebuah kelainan. Tetapi WHO dalam hal ini menganggap bahwa orientasi seksual apapun, termasuk homoseksual, dapat dianggap sebagai kelainan mental jika hubungan tersebut dapat mengakibatkan kelainan mental lain yang harus diobati. ${ }^{25}$ Faktanya, menurut beberapa penelitian kaum gay dan lesbian lebih beresiko mengalami masalah kesehatan mental dibandingkan dengan kaum heteroseksual.

${ }^{20}$ John Bancroft \& June Machover Reinisch, Adolescence and Puberty, Oxford University Press, London, 1990, h. 162.

21 Adonis A. dan Giorgiades, Homosexuality in Ancient Greece : The Myth is Collapsing, Georgiades, Athena, 2004, h. 197-198.

22 Drescher, J. Out of DSM: Depathologizing Homosexuality. 2015. Behavioral Sciences journal. https://www.ncbi.nlm.nih.gov/pmc/articles/PMC4695779/\#

23 Selasar.com. Runtuhnya Gen Gay. https://www.selasar.com/jurnal/13701/Runtuhnya-Teori-Gen-Gay, diakses 18 Juli 2019

24 "Gender Statistics Highlights from 2012 World Development Report". World DataBank, a compilation of databases by the World Bank. February 2012.

${ }^{25}$ Drescher, J. Out of DSM: Depathologizing Homosexuality. 2015. Behavioral Sciences journal. https://www.ncbi.nlm.nih.gov/pmc/articles/PMC4695779/\# 
Masalah kesehatan mental yang paling sering dialami berupa depresi berat, gangguan cemas menyeluruh dan gangguan bipolar. Akibatnya kelompok ini lebih beresiko untuk menggunakan obat-obatan terlarang dan tindakan bunuh diri. Selain itu banyak kaum gay yang dihantui dengan isu dan fakta mengenai penyakit HIV/AIDS yang mematikan. ${ }^{26}$

Tidak hanya beresiko untuk mengalami gangguan mental, penyakit fisik seperti HIV/AIDS dan penyakit menular seksual juga marak di kalangan homoseksual. Pernyataan ini bukan tanpa data, dari 1,1 juta penderita HIV/AIDS di Amerika Serikat pada tahun 2014, 56\% diantaranya merupakan kaum homoseksual atau disebut juga dengan men who have sex with men (MSM). Dua pertiga dari kasus baru setiap tahunnya sejak tahun 2008 juga disumbang oleh kelompok ini. HIV/AIDS merupakan penyakit infeksi virus yang menyerang sistem pertahanan tubuh manusia. ${ }^{27}$

Angka kejadian penyakit menular seksual juga telah meningkat di kalangan gay dan biseksual. Pada tahun 2014 tercatat 83\% gay dan biseksual di Amerika menderita penyakit sifilis primer dan sekunder. Selain itu kelompok ini juga lebih cenderung terkena penyakit menular seksual seperti infeksi gonore. Perilaku seks anal dan oral juga menjadi pencetus masifnya penyebaran Human papilloma virus, dimana virus ini dapat menyebabkan benjolan pada mulut dan kelamin bahkan ada yang berkembang menjadi kanker. ${ }^{28}$

\subsection{Pengaturan Hukum Pidana Indonesia Terkait Homoseksualitas}

Pemidanaan terhadap pelaku homoseksual yang dimaksud dalam tulisan ini adalah pemidanaan terhadap pelaku homoseksual yang melakukannya atas dasar suka sama suka. Tetapi mengingat betapa seringnya kaum homoseksual melakukan perbuatan tersebut kepada orang yang sebenarnya tidak menginginkannya maka hal tersebut juga akan dibahas pada bagian ini.

Aturan hukum yang mengatur mengenai perilaku homoseksual terdapat dalam Pasal 292 Kitab Undang-undang Hukum Pidana, yang berbunyi: Orang yang cukup umur, yang melakukan perbuatan cabul dengan orang lain sama kelamin, yang diketahui atau sepatutnya harus diduga, bahwa belum cukup umur, diancam dengan pidana penjara paling lama lima tahun.

Sugandhi menyatakan bahwa perbuatan cabul ialah setiap perbuatan yang bertentangan dengan kesusilaan atau perbuatan keji yang berkaitan dengan nafsu kelamin bukan dalam artian persetubuhan, misalnya berciuman, meraba anggota kemaluan, dll. ${ }^{29}$ Definisi perbuatan cabul tersebut menunjukkan bahwa perbuatan itu dapat terjadi antara laki-laki dengan laki-laki, laki-laki dengan perempuan, maupun perempuan dengan perempuan karena dikecualikannya persetubuhan dari perbuatan

\footnotetext{
${ }^{26}$ Gay and Bisexual Men's Health : Mental Health. Central for Disease Control and Prevention. United States. 2016. https://www.cdc.gov/msmhealth/mental-health.htm

${ }^{27}$ Gay and Bisexual Men's Health : HIV/AIDS. Central for Disease Control and Prevention. United States. 2016. https:// www.cdc.gov/msmhealth/mental-health.htm

${ }^{28}$ Gay and Bisexual Men's Health : Sexual transmitted Disease. Central for Disease Control and Prevention. United States. 2016. https://www.cdc.gov/msmhealth/sexual-transmitteddisease.htm

${ }^{29}$ R. Sugandhi, KUHP Dan Penjelasannya, Usaha Nasional, Surabaya, 1980. h. 306.
} 
tersebut. Persetubuhan itu sendiri berarti masuknya kelamin laki-laki ke dalam kelamin perempuan. ${ }^{30}$

Pelakunya harus orang dewasa, kriteria dewasa dalam pasal tersebut sama dengan belum dewasa menurut Pasal 330 BW yaitu seseorang yang telah berumur 21 tahun atau pernah menikah. Maka dengan analogi acontrario yang dikatakan belum dewasa ialah orang yang belum menikah atau umurnya belum mencapai 21 tahun. ${ }^{31}$

Pasal 292 KUHP tersebut mensyaratkan bahwa korbannya adalah "kelamin yang sejenis" yakni laki-laki dan laki-laki atau perempuan dan perempuan.32 Tidak adanya ketentuan dalam pasal tersebut yang mensyaratkan bahwa ada salah satu pihak yang terpaksa, tertipu, maupun terbujuk menunjukkan bahwa pasal tersebut dikenakan bagi orang yang melakukannya dengan suka sama suka.

Meskipun pasal tersebut dikenakan bagi pelaku homoseksual yang suka sama suka, namun yang menjadi subjek hukum dan yang dibebani tanggung jawab pidana ialah siapa diantara kedua orang tersebut yang sudah dewasa ${ }^{33}$, sedangkan yang belum dewasa tidak dibebani pertanggungjawaban pidana. Jadi dua pasangan homoseksual yang sudah dewasa yang melakukan perbuatan cabul tidak dapat dipidana berdasarkan pasal tersebut.

Pelaku homoseksual terkadang melakukan perbuatan seksual yang abnormal tersebut kepada orang yang tidak menginginkannya. Untuk kasus-kasus seperti ini banyak aturan hukum pidana di Indonesia yang bisa dikenakan terhadap pelakunya. Terhadap orang yang dengan kekerasan atau ancaman kekerasan memaksa seorang untuk melakukan atau membiarkan dilakukan perbuatan cabul, diancam dengan pidana penjara paling lama sembilan tahun. ${ }^{34}$ Terhadap orang yang melakukan perbuatan cabul dengan orang yang pingsan atau tidak berdaya dapat dipidana dengan pidana penjara maksimal tujuh tahun. ${ }^{35}$. Terhadap orang yang melakukan perbuatan cabul dengan orang yang belum berumur lima belas tahun dapat dipidana dengan pidana penjara maksimal tujuh tahun. ${ }^{36}$ Bahkan terhadap orang yang membujuk seseorang yang belum berumur lima belas tahun untuk melakukan atau membiarkan dilakukan perbuatan cabul dengan orang lain dapat juga dipidana dengan pidana penjara maksimal tujuh tahun. ${ }^{37}$ Dalam Undang-Undang RI Nomor 23 tahun 2002 tentang Perlindungan Anak hukuman terhadap perbuatan cabul telah ditambah menjadi paling lama 15 tahun dan paling singkat 3 tahun.

Ketiadaan aturan pidana yang dapat menjerat pelaku homoseksual yang sudah dewasa dan melakukannya dengan suka sama suka tersebut berlaku di seluruh Indonesia kecuali di Aceh. Indonesia telah berupaya melakukan pembaharuan terhadap hukum pidana dengan membuat KUHP Nasional yang berlandaskan Pancasila, berbeda dengan KUHP yang berlaku sekarang dimana isinya berasal dari

\footnotetext{
30 Ibid, h. 301.

31 Adami Chazawi, Tindak Pidana Mengenai Kesopanan, Pt. RajaGrafindo Persada, Jakarta, 2005, h. 89.

32 Op. Cit, R. Sugandhi, h. 309.

33 Op. Cit, Adami Chazawi, h. 89.

34 Pasal 289 KUHP.

35 Pasal 290 ayat (1) KUHP.

36 Pasal 290 ayat (2) KUHP.

37 Pasal 290 ayat (3) KUHP.
} 
nilai dan budaya yang ada di Belanda sehingga tidak sesuai dengan kehidupan bangsa Indonesia. Namun hingga sekarang KUHP Nasional tersebut belum disahkan. ${ }^{38}$

Dalam Qanun Jinayat Aceh menyebut homoseksual yang terjadi antara sesama lakilaki dengan Liwath, dan menyebut homoseksual yang terjadi antara sesama perempuan dengan Musahaqah. Liwath ialah perbuatan seorang laki-laki dengan cara memasukkan zakarnya ke dalam dubur laki-laki yang lain dengan kerelaan kedua belah pihak. ${ }^{39}$ Sedangkan Musahaqah ialah perbuatan dua orang wanita atau lebih dengan cara saling menggosok-gosokkan anggota tubuh atau faraj untuk memperoleh rangsangan (kenikmatan) seksual dengan kerelaan kedua belah pihak. 40

Aturan tersebut ternyata masih memiliki kelemahan dalam perumusan normanya. Unsur "masuknya zakar ke dalam dubur laki-laki lain" pada tindak pidana liwath menunjukkan bahwa yang dapat dipidana hanya pasangan homoseksual yang melakukan anal seks, sementara bentuk hubungan seks lainnya sebagaimana perbuatan cabul dalam KUHP seperti berciuman, meraba-raba alat kelamin, dan oral seks tidak dapat dipidana.

Kelemahan juga terlihat pada unsur "menggosok-gosokkan anggota tubuh atau faraj" pada tindak pidana musahaqah. Yang "digosok-gosokkan" adalah anggota tubuh perempuan dengan perempuan. Tetapi bagaimana jika pelaku musahaqah menggunakan alat bantu seks (sex toys) seperti dildo atau benda-benda lainnya seperti gagang sapu, terong, dll dalam melakukan hubungan seksual sesama perempuan? Tentu mereka tidak akan dapat dipidana berdasarkan tindak pidana ini.

Sejauh pengetahuan penulis tidak ada satu pun norma dalam Qanun Jinayat yang dapat menjerat pelaku homoseksual yang hanya sekedar meraba-raba, berciuman, dan oral seks. Tindak pidana ikhtilath yang digunakan untuk menghukum perbuatan meraba-raba tersebut pun hanya ditujukan bagi hubungan seksual antara laki-laki dan perempuan ${ }^{41}$, tidak untuk hubungan sejenis.

Dari penjelasan di atas dapat penulis simpulkan bahwa aturan hukum pidana di Indonesia (termasuk Aceh) belum mengatur dan mengancam pidana terhadap pelaku homoseksual secara holistik.

\subsection{Hakikat Pelanggaran Hak Asasi dan Kewajiban Asasi Oleh Pelaku Homoseksual}

NKRI menjamin tegaknya hak asasi manusia dalam konstitusinya, tak terkecuali hak melanjutkan keturunan. Dalam Pasal 28B ayat (1) UUD 1945 Pasca Amandemen dinyatakankan bahwa setiap orang berhak membentuk keluarga dan melanjutkan keturunan melalui perkawinan yang sah. Aturan yang demikian juga terdapat di dalam Pasal 10 ayat (1) UU HAM.

Seorang laki-laki berhak untuk melanjutkan keturunan yang didapatnya melalui hubungan seksual yang legal dengan perempuan. Dan begitu juga seorang wanita

\footnotetext{
38 Harahap Hasangapon Tua Indra, 2018. Kebijakan Hukum Pidana Dalam Upaya Menanggulangi LGBT (Lesbian, Bisekssual, dan Transgender) Berbasis Pancasila. Masalah-Masalah Hukum, Jilid 47 No. 4, Oktober 2018, h. 400-412.

39 Pasal 1 angka 28 Qanun Jinayat.

40 Pasal 1 angka 29 Qanun Jinayat.

${ }^{41}$ Pasal 1 angka 24 Qanun Jinayat.
} 
berhak untuk melanjutkan keturunannya melalui hubungan seksual yang legal dengan seorang laki-laki. Merupakan hal yang mustahil hubungan seksual antara makhluk yang sama-sama memiliki sperma saja atau sama-sama memiliki sel ovum saja dapat menghasilkan keturunan.

Tetapi akhir-akhir ini ada pasangan homoseksual Theo dan Christo dari Afrika Selatan mengklaim bahwa mereka telah mempunyai anak dari buah cintanya. Mereka menyatakan bahwa anak tersebut dimiliki dengan cara penanaman, yaitu dua embrio dibuahi, sperma Cristo dan Sperma Theo di tanam dalam rahim seorang wanita. ${ }^{42}$ Jadi mereka menganggap bahwa sperma mereka berdua bersatu di dalam rahim perempuan tersebut sehingga menghasilkan anak.

Sedangkan menurut ilmu kedokteran sel ovum perempuan hanya bisa dibuahi oleh satu sel sperma saja. Ketika satu sel sperma masuk ke dalam sel ovum maka melalui berbagai mekanisme, sel ovum tersebut akan menutup diri terhadap sel sperma yang lain. ${ }^{43}$ Jadi sebenarnya anak yang lahir dari rahim perempuan tersebut adalah anak salah satu dari Theo atau Christo dengan si perempuan, bukan anak pasangan homoseksual tersebut.

Anak yang lahir tentunya akan dibuatkan akta kelahiran. Salah satu unsur yang pasti ada dalam akta kelahiran adalah nama kedua orang tua si anak. Bagi pasangan homoseksual tentunya mereka akan mencantumkan nama mereka berdua sebagai orang tua si anak. Tidak mungkin mereka mencantumkan nama perempuan yang dipinjam rahimnya sebagai orang tua si anak. Jika hanya nama salah satu dari pasangan tersebut dan perempuan yang dipinjam rahimnya yang dicantumkan di dalam akta kelahiran, pastilah pasangan homoseksualnya akan marah dan berkata "Sebenarnya itu buah cinta kita berdua atau buah cintamu bersama perempuan itu?"

Tidak dicantumkannya nama si perempuan sebagai orang tua si anak merupakan pelanggaran terhadap hak anak sebagaimana termaktub dalam Article 7 paragraph 1 Convention on The Rights of The Child yaitu The child shall be registered immediately after birth and shall have the right from birth to a name, the right to acquire a nationality and. as far as possible, the right to know and be cared for by his or her parents (Anak harus didaftarkan segera setelah dilahirkan dan harus memiliki hak sejak lahir atas suatu nama, hak untuk memperoleh kewarganegaraan, dan sejauh mungkin, hak untuk mengetahui dan dirawat oleh orang tuanya). Dengan tidak dicantumkannya nama perempuan yang dipinjam rahimnya sebagai orang tua si anak maka dengan sendirinya hal itu menjadi pelanggaran terhadap hak anak untuk mengetahui orang tuanya. Ditambah lagi dengan kenyataan pahit yang diterima si anak karena mempunyai ayah dan ibu yang keduanya berkumis.

Kewajiban asasi manusia adalah menghormati, melindungi, memenuhi, dan mengembangkan hak asasi orang lain. Pemahaman terhadap kebebasan dan tanggung

42 Wajibbaca.com. (2016). Heboh! Pasangan Gay Tulen Ini Punya Anak Kandung Kembar 3!. https://www.wajibbaca.com/2016/08/heboh-pasangan-gay-tulen-ini-punya-anak.html

${ }^{43}$ Sarwono Prawirohardjo, Ilmu Kebidanan, PT Bina Pustaka Sarwono Prawirohardjo, Jakarta, 2010, hlm 141. Kalimat di atas bukanlah kalimat asli dari buku tersebut. Tetapi sudah disederhanakan dengan kalimat yang lebih mudah dipahami berdasarkan wawancara dengan Muhammad Arief Lubis, S.Ked. 
jawab diakui sebagai penyeimbang terhadap konsep kewajiban manusia. Kewajiban berhubungan dengan tanggung jawab dan hak berhubungan dengan kebebasan. ${ }^{4}$

Pada hakikatnya pelaku homoseksual telah mengurangi atau minimal mencegah dan menghambat terpenuhinya hak asasi orang lain untuk mendapatkan keturunan. Kaum lesbian telah menghambat hak laki-laki untuk mendapat keturunan, begitu juga kaum gay telah menghambat hak perempuan untuk mendapat keturunan. Bahkan kaum homoseksual telah menghambat hak laki-laki dan perempuan yang heteroseksual untuk mendapatkan hak-hak menikmati hubungan seksualnya.

Pada bagian B Hasil Penelitian ini telah dibahas bahwa tidak ada literatur yang menyebutkan bahwa kurangnya jumlah perempuan menyebabkan meningkatnya jumlah homoseksual. Pernyataan tersebut adalah benar karena kondisi yang ada bukan kurangnya perempuan tetapi kurangnya laki-laki dan lebihnya perempuan. Dengan permasalahan jumlah kelebihan perempuan di dunia, hak-hak seksual perempuan menjadi semakin terhambat. Mungkin hal ini tidak terlalu terasa di Indonesia. Tetapi hal ini menjadi masalah di negara-negara barat.

Ahmad Deedat bahkan telah menjelaskan kondisi ini 23 tahun lalu dalam bukunya yang fenomenal, The Choice, Islam and Christianity. Berikut pernyataan beliau:

Setiap Negara mengalami kelebihan wanita. Inggris 4 juta, Jerman 5 juta, Soviet Rusia 7 juta dan lain-lain. Amerika Serikat mengalami kelebihan wanita sekitar 7.8 juta. Itu berarti apabila setiap pria di sana menikah, masih banyak juga wanita yang tinggal tanpa suami. Masalah ini merupakan hal yang kompleks. Penjara di sana dihuni 98\% diantarnya pria, dan ada sekitar 25 juta pelaku sodomi. Kata "gay" telah diselewengkan disebut sebagai kata yang indah dan gembira. Hal ini juga terjadi di Kota New York, kelebihan wanita di kota ini sekitar 1 juta jiwa. Yang lebih parah lagi 1/3 pria di kota ini adalah kaum homoseksual. 45

Perempuan yang tadinya heteroseksual bisa menjadi homoseksual karena tidak ada lelaki yang menyentuhnya. Umat manusia yang sudah sedikit jumlahnya akibat wabah penyakit, perang dan bencana alam akan semakin sedikit jumlahnya karena sedikitnya kelahiran akibat begitu banyaknya orang yang menjadi homoseksual.

Pada bagian B Hasil Penelitian ini juga telah dijelaskan bahwa HIV/AIDS meningkat di antara kaum homoseksual di Amerika. Sampai tulisan ini dibuat belum ada suatu pengobatan spesifik yang dapat menyembuhkan penyakit ini, bahkan WHO sendiri menyatakan bahwa mengontrol progresivitas penyakit merupakan satu-satunya jalan bagi mereka yang sudah terkena, sehingga pada akhirnya penderita dapat mengalami kematian yang diikuti oleh penderitaan jangka panjang akibat ini. Sejak pertama kali menyebar sampai saat ini, HIV/AIDS telah menjangkiti sekitar 70 juta manusia di seluruh dunia dimana setengah dari jumlah tersebut telah mengalami kematian. Penelitian skala besar yang merangkum 52 penelitian menyimpulkan bahwa $82 \%$ penderita HIV akan berkembang menjadi AIDS (HIV stadium akhir) dalam 10 tahun. Kemudian, penderita AIDS hanya dapat bertahan selama 2 tahun tanpa pengobatan

\footnotetext{
${ }_{44}$ Jimly Asshiddiqie, Pengantar Ilmu Hukum Tata Negara, Rajawali Pers, 2009, h. 368.

${ }^{45}$ Ahmad Deedat, The Choice, Dialog Islam-Kristen, Al-Kautsar, Jakarta, 1999, h. 83-84.
} 
antivirus dan kurang lebih 10 tahun hanya jika menjalani pengobatan antivirus secara teratur. 46

HIV/AIDS menyebabkan kematian melalui pelemahan terhadap sistem imunitas tubuh manusia. Normalnya, walaupun manusia hidup ditengah-tengah jutaan virus dan bakteri, manusia terlindungi dari banyak penyakit infeksi dengan adanya sistem imun. Jika sistem ini melemah, maka akan banyak penyakit infeksi yang akan menjangkiti si penderita HIV. Terhitung hampir semua penyakit infeksi dapat dengan mudah mengenai penderita HIV, mulai dari infeksi ringan hingga infeksi berat, seperti tuberkulosis paru, radang paru, hepatitis B dan C dan gangguan kejiwaan (depresi, cemas dan bipolar) serta infeksi menular seksual (gonore, sifilis, herpes simpleks, human papilloma virus). ${ }^{47}$

Seorang penderita HIV dapat terkena beberapa penyakit dalam satu waktu, bahkan beberapa diantaranya dapat terkena beberapa penyakit kronis lainnya yang juga belum dapat disembuhkan sampai saat ini seperti hepatitis B. Beberapa penyakit lainnya menuntut pengobatan jangka panjang untuk dapat disembuhkan, seperti tuberkulosis paru dan sifilis. Maka dapat dibayangkan seseorang dengan HIV harus minum beberapa jenis obat untuk mengobati berbagai jenis penyakit oportunistik tersebut. Obat-obatan tersebut bukan tanpa efek samping, terutama dalam menimbulkan penurunan nafsu makan. Maka tidak heran orang dengan HIV akan semakin kurus dari hari ke hari, disamping asupan makanan yang kurang, juga diakibatkan oleh bakteri atau virus yang menggerogoti tubuhnya. Selain itu, mereka juga hidup di tengah ketakutan dan tekanan akibat penyakit-penyakit yang terus timbul, sehingga tidak sedikit dijumpai masalah depresi berat hingga berujung pada perbuatan bunuh diri pada kelompok ini. ${ }^{48}$

Penjabaran di atas bukanlah bertujuan menakut-nakuti atau merendahkan mereka yang telah terkena, namun hal itu harus diketahui oleh orang banyak terutama bagi mereka yang belum terinfeksi virus-virus tersebut. "Mencegah lebih baik daripada mengobati", itulah slogan yang sering dikumandangkan oleh para aktivis kesehatan. Salah satu langkah pencegahan yang paling utama yaitu dengan menghindari perbuatan yang menjadi faktor resiko penyebaran penyakit tersebut. Perilaku homoseksual memang bukan satu-satunya faktor resiko dalam penularan HIV, namun perilaku homoseksual tetaplah sebagai salah satu jalan masuk. Pelaku homoseksual mungkin dapat berdalih akan menggunakan berbagai cara untuk mencegah penularan penyakit. Penggunaan berbagai alat kontrasepsi dan obat-obatan dalam memutus rantai penularan belumlah se efektif yang diharapkan, karena banyaknya jalan masuk bagi virus di samping perilaku tersebut mungkin dapat mengundang perilaku beresiko yang lain. Dalam hal ini penting bagi kita untuk mengerti dan memahami secara holistik dan komprehensif tentang bahaya perilaku ini.

Orang yang sudah tertular HIV/AIDS tetaplah membutuhkan hubungan seksual. Ketika orang yang sudah terjangkit HIV/AIDS melakukan hubungan seksual dengan

${ }^{46}$ World Health Organization. 2017. http://www.who.int/gho/hiv/en/

47 Poorolajal. J, 2016, Survival rate of AIDS disease and mortality in HIV-infected patients: a meta-analysis. Public Health Journal. h. 3-9

48 Nlooto M. 2017. Comorbidities of HIV Infection and Health Care Seeking Behavior among HIV Infected Patients Attending Public Sector Healthcare Facilities in KwaZulu-Natal : A Cross Sectional Study. Plos One Journal. Available at : www.journals.plos.org/plosone/article/id=10.1371/journal.pone. 0170983 
orang yang sehat, pada hakikatnya orang tersebut telah melanggar hak asasi orang lain untuk hidup, mempertahankan, meningkatkan taraf kehidupannya, serta melanggar hak orang lain untuk mendapatkan jaminan kesehatan.

Hak Asasi selalu berjalan seiring dengan kewajiban asasi. Hak untuk tidak dilukai dan dibunuh juga berarti kewajiban untuk tidak melukai dan membunuh. Aturan ini tersirat dari Pasal 6 Declaration Universal of Human Responsibilty (DUKAM), yaitu: No one, except in the case of self-defense, has the right to injure or to kill. Every human being ought rather to have respect for life (Tidak satu orang pun, kecuali dalam kasus bela diri, punya hak untuk melukai atau membunuh. Setiap manusia seharusnya lebih menghormati kehidupan).

Manusia berkewajiban untuk tidak melukai dan membunuh orang lain. Seorang pengidap HIV/AIDS yang melakukan hubungan seksual dengan orang yang sehat pada hakikatnya sedang melakukan pelukaan bahkan pembunuhan. Pelukaan tidak harus terlihat sebagaimana tangan yang tergores pisau. Suatu luka akibat goresan pisau di tangan menimbulkan rasa sakit. Begitu juga penyakit yang ada di tubuh bagian dalam manusia menimbulkan rasa sakit. Maka penularan penyakit dapat dianalogikan dengan pelukaan.

Pembunuhan juga tidak harus menyebabkan si korban mati seketika. Pembunuhan secara perlahan-lahan/dengan penyiksaan pun tetap dapat dikategorikan sebagai pembunuhan. Hal ini koheren dengan penjelasan sebelumnya bahwa jika tidak mati dalam waktu yang singkat, penderita HIV/AIDS akan menderita sepanjang hidup sebelum kematiannya.

Walaupun niat pengidap HIV/AIDS ketika melakukan hubungan seksual dengan orang sehat bukanlah untuk membunuhnya ataupun melukainya, hal ini tidak bisa dijadikan dalih bahwa perbuatan yang demikian bukan perbuatan yang jahat. Secara logis, akibat buruk yang diperkirakan timbul dari suatu perbuatan harus dicegah sedapat mungkin. Jika akibat buruk tersebut tidak dapat dipastikan hilang maka harus ditutup pintu masuknya yaitu dengan mencegah perbuatannya terjadi. Oleh karena itu perbuatan seorang pengidap HIV/AIDS yang melakukan hubungan seksual dengan orang yang sehat walaupun tanpa niat menularkan penyakit tetaplah masuk kategori perbuatan buruk.

Berdasarkan penjelasan-penjelasan bagian ini dapat dilihat bahwa pada hakikatnya pelaku homoseksual telah melanggar hak asasi/merugikan orang lain sekaligus melanggar kewajiban asasinya. Pelanggaran hak asasi dan kewajiban asasi pada dasarnya adalah ketidakpatuhan pada perintah untuk melindungi hak asasi orang lain serta mengerjakan larangan untuk tidak mengganggu hak asasi orang lain. Dalam ilmu hukum, menolak perintah dan mengerjakan larangan adalah perbuatan yang layak diberi sanksi. Oleh karena itu Penulis berkesimpulan bahwa pelaku homoseksual dalam bentuk apapun, dan kondisi bagaimanapun tetap layak dipidana.

\subsection{Tanggung Jawab Negara dalam Menanggulangi Bahaya Homoseksualitas}

Setiap sistem hukum dalam suatu Negara harus adanya tanggung jawab terhadap setiap kegagalan dalam melaksanakan kewajiban yang dibebankan oleh 
peraturannya. ${ }^{49}$ Begitu pula dalam penegakan HAM, negara bertanggungjawab atas setiap kegagalan dalam melaksanakan kewajiban yang dibebankan oleh hukum internasional maupun hukum nasional. Salah satu hak yang menjadi tanggung jawab negara adalah hak seksualitas, namun pemerintah masih abai dan lalai dalam pemenuhan hak tersebut, jika dilihat dari data yang dikeluarkan oleh LSM Arus Pelangi bahwa 89.3\% kaum LGBT pernah mengalami kekerasan karena identitas seksualnya. ${ }^{50}$

Tanggung jawab dan kewajiban negara terhadap HAM adalah menghormati, melindungi, menegakkan, dan memajukan HAM tersebut. ${ }^{51}$ Sebagaimana telah kita bahas sebelumnya bahwa hak asasi selalu berjalan seiring dengan kewajiban asasi. Maka wujud nyata tanggung jawab dan kewajiban negara dalam konteks hubungan hak dan kewajiban asasi manusia tersebut dapat dirinci sebagai berikut:

- Memastikan hak asasi setiap orang terpenuhi.

- Memastikan setiap orang melakukan kewajiban asasinya.

- Menjatuhkan punishment bagi orang yang melanggar, membatasi, menghambat hak asasi orang lain.

- Menjatuhkan punishment bagi orang yang tidak memenuhi kewajiban asasinya.

Bila ditinjau dari sisi hukum, tata pergaulan, adat kebiasaan, sejarah, dan pola hidup bangsa Indonesia pada umumnya, bahwa bangsa Indonesia sudah memiliki dan mengenal segala hal yang berhubungan dengan Hak Asasi Manusia. Hal ini dapat dibuktikan dari pernyataan yang sudah dikenal sejak nenek moyang, antara lain pusako jo kato mufakat, gotong royong, tut wuri handayani, dll. ${ }^{52}$ Tetapi tentu saja ideide tentang hak asasi dalam masyarakat di Nusantara tersebut berjalan beriringan dengan kewajiban asasi dalam konteks masyarakat yang komunal.

Salah satu nilai yang hidup di masyarakat Indonesia adalah nilai agama. Nilai agama tersebut diformulasikan dalam sila pertama Pancasila yaitu Ketuhanan Yang Maha Esa. Perumusan kalimat tersebut sebagai sila pertama merupakan sinyal bahwa kita harus mendahulukan prinsip-prinsip agama sebelum prinsip yang lainnya. Agama lebih utama daripada kemanusiaan, persatuan, kerakyatan, dan keadilan walaupun sebenarnya unsur dari prinsip-prinsip yang lain tersebut sudah terdapat dalam prinsip agama. Menurut ketua AILA, Rita Soebagio bahwa undang-undang dapat dibentuk dengan mengkaji nilai moral terhadap orientasi dan perilaku LGBT yang merupakan penyimpangan terhadap setiap nilai-nilai yang hidup dalam masyarakat Indonesia. ${ }^{53}$

Fenomena LGBT di indonesia disebabkan oleh masuknya pengaruh budaya asing dan maraknya pergaulan bebas yang dewasa ini terjadi. Homoseksualitas adalah perbuatan yang dipandang buruk oleh mayoritas masyarakat indonesia dan bertentangan dengan

${ }^{49}$ C. De Rover, To Serve \& To Protect, Acuan Universal Penegakan HAM, PT.RajaGrafindo Persada, Jakarta, 2000, h. 21.

50 Masthuriyah Sa'dan, "LGBT dalam Perspektif Agama dan HAM", dalam Jurnal NIZHAM, Vol.05, No.01 UIN Sunan Kalijaga Yogyakarta, h. 22.

51 Pasal 71 UU HAM.

52 Masyhur Effendi, Dimensi/Dinamika Hak Asasi Manusia dalam Hukum Nasional dan Internasional, Ghalia Indonesia, Jakarta,1994, h. 134

53 Widayati Suryani Lidya, 2018, Kriminalisasi Perbuatan Cabul Lesbian, Gay, Biseksual, Dan Transgender(LGBT), Pusat Penelitian Badan Keahlian DPR RI, Vol. X, No.03/I/Puslit/Februari/2018. h. 4 
nilai-nilai yang hidup di indonesia. ${ }^{54}$ Sepengetahuan Penulis, dari agama yang di akui Indonesia tidak ada satu agama yang membenarkan praktik homoseksual. Masyarakat Indonesia secara umum memandang perbuatan homoseksual sebagai perbuatan yang amoral yang dilindungi oleh pendukungnya dengan tameng hak asasi. Padahal hak asasi manusia di Indonesia haruslah tetap berada dalam bingkai moral sebagaimana yang termaktub dalam Pasal 70 UU HAM yaitu:

Dalam menjalankan hak dan kebebasannya, setiap orang wajib tunduk kepada pembatasan yang ditetapkan oleh Undang-undang dengan maksud untuk menjamin pengakuan serta penghormatan atas hak dan kebebasan orang lain dan untuk memenuhi tuntutan yang adil sesuai dengan pertimbangan moral, keamanan, dan ketertiban umum dalam suatu masyarakat demokratis.

Singkatnya, keagamaan dan moral terpatri sangat kuat dalam bingkai NKRI. Berdasarkan kenyataan tersebut maka negara berhak dan berkewajiban untuk menjatuhkan pidana kepada pelaku homoseksual karena homoseksual tersebut dilarang dalam semua ajaran agama yang ada di Indonesia.

Di sub-bab D bab ini telah dijelaskan bahwa pada hakikatnya pelaku homoseksual telah melanggar hak asasi orang lain dan melanggar kewajiban asasinya. Tindak pidana yang diatur di KUHP juga merupakan tindakan yang punya hakikat serupa. Contohnya pencurian adalah pelanggaran terhadap HAM untuk mempunyai hak milik, Kelalaian yang menyebabkan matinya orang adalah pelanggaran terhadap kewajiban asasi. Oleh karena itu secara kefilsafatan, negara berhak bahkan berkewajiban untuk menjatuhkan pidana terhadap pelaku homoseksual.

Penyakit HIV/AIDS kebanyakan menyebar pada hubungan seksual sesama jenis. Sebelumnya telah dijelaskan tentang begitu berbahayanya penyakit ini. Maka salah satu wujud perlindungan negara terhadap masyarakat di bidang kesehatan untuk mencegah penyebaran penyakit ini adalah dengan cara memberikan ancaman pidana kepada pelaku homoseksual.

Berdasarkan pembahasan pada bagian A Hasil Penelitian ini telah dijelaskan bahwa pada hakikatnya pemidanaan adalah pelanggaran terhadap HAM, tetapi berdasarkan Pasal 1 CAT pemidanaan/penyiksaan yang berdasarkan hukum dikecualikan dari pelanggaran HAM. HAM itu sendiri memiliki sifat relatif yang dapat dipraktikkan berbeda pada tempat yang berbeda. Satu tindakan yang dikriminalisasi di sebuah negara namun tidak dikriminalisasi di negara lain merupakan hal yang sah-sah saja. DUHAM adalah standar umum penegakan HAM, sedangkan standar khususnya adalah hukum nasional suatu negara. Oleh karena itu Penulis berkesimpulan bahwa jika seandainya dilakukan kriminalisasi dan penjatuhan pidana terhadap lakilaki/wanita dewasa homoseksual yang melakukannya atas dasar suka sama suka, hal itu bukanlah suatu pelanggaran terhadap HAM.

54 Wawan Setiawa, Yuditiya Dyah Sukmadewi, Peran Pancasila pada Era Globalisasi Kajian terhadap Pancasila dan Fenomena LGBT di Indonesia, Jurna Dinamika Sosial Budaya Vol 19 No. 1, juni 2017, h. 135. 


\section{Kesimpulan}

Pemidanaan terhadap suatu perbuatan oleh suatu negara dimana perbuatan tersebut tidak dipidana di negara lain merupakan hal yang dapat dibenarkan berdasarkan HAM dalam perspektif Relativisme HAM, yaitu doktrin pada intinya mengajarkan bahwa HAM dapat dipraktikkan berbeda pada tempat yang berbeda. Pelaku homoseksual layak dipidana karena pada hakikatnya pelaku homoseksual telah melanggar hak asasi/merugikan orang lain sekaligus melanggar kewajiban asasinya. Pemidanaan terhadap pelaku homoseksual yang melakukannya suka sama suka dengan orang yang belum dewasa di seluruh Indonesia (kecuali Aceh), Pemidanaan terhadap pelaku tindak pidana liwath dan musahaqah di Aceh, dan jika di masa yang akan datang pemidanaan terhadap laki-laki/wanita dewasa homoseksual yang suka sama suka diterapkan di Indonesia, semuanya bukanlah merupakan pelanggaran HAM. Hal ini merupakan konsekuensi dari Pasal 1 CAT yang pada intinya menyatakan bahwa pemidanaan/penyiksaan yang berdasarkan hukum dikecualikan dari pelanggaran HAM.

\section{Daftar Pustaka \\ $\underline{\text { Buku }}$}

Al-Attas, S. M. N. (2015). On Justice and the Nature of Man: A Commentary on Surah Al-nisa (4): 58 and Surah Al-mu'minun (23): 12-14. Kuala Lumpur: IBFIM.

Alkatiri, Z. J. (2010). Belajar memahami HAM. Depok: Ruas.

Asshiddiqie, J. (2009) Pengantar Ilmu Hukum Tata Negara. Jakarta: Rajawali Pers

Bancroft, J., \& Reinisch, J. M. (Eds.). (1990). Adolescence and puberty. London: Oxford University Press.

Cassese, A. (1994). Hak Asasi Manusia di Dunia yang Berubah. Jakarta: Yayasan Obor Indonesia.

Chazawi, A. (2005). Tindak pidana mengenai kesopanan. Jakarta: RajaGrafindo Persada.

De, C. (2016). To Serve \& To Protect: Acuan Universal Penegakan HAM. Jakarta: PT.Raja Grafindo Persada.

Deedat, A. (1999). THE CHOICE: Dialog Islam-Kristen: Dialog Islam VS Kristen. Jakarta: Pustaka Al Kautsar.

Effendi, A. M. (1994). Dimensi/dinamika hak asasi manusia dalam hukum nasional dan internasional. Jakarta: Ghalia Indonesia.

Feldmen, R. S. (1990). Understanding Psychology, Second Edition. New York: Mc GrawHill Publishing Company

Georgiadis, A. (2004). Homosexuality in Ancient Greece: The Myth is Collapsing. Athens: Hellenike Agoge

Nietzel, dkk. (1998). Abnormal Psychology, Boston: Allyn dan Bacon.Inc

Plato. (1972). Laws, Book VIII, Penguin Books

Pickett, B. L. (2009). The Historical Dictionary of Homosexuality, Marryland: The Scarecrow press

Prawirohardjo, S. (2010). Ilmu Kebidanan Sarwono Prawirohardjo. Jakarta: PT. Bina Pustaka.

Ruggiero, G. (1989). The boundaries of eros: Sex crime and sexuality in Renaissance Venice. Studies in the History of Sexuality. London: Oxford University Press.

Sugandhi, R. (1980). KUHP Dan Penjelasannya, Surabaya: Usaha Nasional 


\section{Jurnal}

Boellstorff, T. (2014). Gay dan Lesbian Indonesia serta Gagasan Nasionalisme. Antropologi Indonesia, 30(1). https://doi/org/10.7454/ai.v30i1.3550

Drescher, J. (2015). Out of DSM: Depathologizing homosexuality. Behavioral Sciences, 5(4), 565-575. https://doi.org/10.3390/bs5040565

Harahap, I. T. H. (2018). Kebijakan Hukum Pidana dalam Upaya Menanggulangi LGBT (Lesbian, Biseksual, dan Transgender) Berbasis Pancasila. Masalah-Masalah Hukum, 47(4), 400-412.

Lidya, Suryani, W. (2018). Kriminalisasi Perbuatan Cabul Lesbian, Gay, Biseksual, Dan Transgender(LGBT), Pusat Penelitian Badan Keahlian DPR RI, X(3).

Sa, M. (2016). LGBT dalam Perspektif Agama dan HAM. Nizham Journal of Islamic Studies, 4(1), 16-25.

Santoso, M. B. (2016). LGBT dalam Perspektif Hak Asasi Manusia. Share: Social Work Journal, 6(2), 154-272. https://doi.org/10.24198/share.v6i2.13206

Setiawan, W., \& Sukmadewi, Y. D. (2017). "Peran Pancasila Pada Era Globalisasi" Kajian Terhadap Pancasila dan Fenomena LGBT (Lesbian, Gay, Bisexual, Transgender) di Indonesia. Jurnal Dinamika Sosial Budaya, 19(1), 126-147. http://dx.doi.org/10.26623/jdsb.v19i1.691

\section{Peraturan Perundang-Undangan}

Convention on The Rights of The Child, 1989.

Convention Againts Torture and Other Cruel, Inhuman or Degrading Treatment or Punishment, 1984.

The Universal Declaration of Human Responsibilities, 1997.

The Universal Declaration of Human Rights, 1948.

Undang-Undang RI Nomor 1 Tahun 1946 tentang Kitab Undang-Undang Hukum Pidana.

Undang-Undang RI Nomor 39 Tahun 1999 Tentang Hak Asasi Manusia.

Undang-Undang RI Nomor 23 Tahun 2002 Tentang Perlindungan Anak.

Qanun Aceh Nomor 6 Tahun 2014 Tentang Hukum Jinayat.

\section{Website}

The Worls Bank. Gender Highlights: 2012 World Development Report.

https://datacatalog.worldbank.org/dataset/gender-highlights-2012-worlddevelopment-report. diakses Pebruari 2012

Newsokezone.com. Polisi Arab Saudi Gerebek Pesta Gay di Jeddah. http://news.okezone.com/read/2015/06/16/18/1166042/polisi-arab-saudigerebek-pesta-gay-di-jeddah

Thisisgender.com. (2016) Sejarah Homoseksual: Penyimpangan yang Melintas Zaman. https://thisisgender.com/sejarah-homoseksual-penyimpangan-yang-melintaszaman/

Selasar.com. Runtuhnya Geori Gay. https://www.selasar.com/jurnal/13701/Runtuhnya-Teori-Gen-Gay, diakses 18 Juli 2019

Tribunnews.com. (2016). Kamerad Prihatin Kaum Homoseksual di Indonesia Kian Memperlihatkan

Eksistensinya. https://www.tribunnews.com/metropolitan/2016/09/23/kamerad-prihatinkaum-homoseksual-di-indonesia-kian-memperlihatkan-eksistensinya 
Tribunnews.com. (2016). Warga Rukoh Tangkap Pasangan Homoseksual, saat Digerebek Keduanya Sedang Tanpa Busana. https://www.tribunnews.com/regional/2017/03/29/warga-rukoh-tangkappasangan-homoseksual-saat-digerebek-keduanya-sedang-tanpa-busana

Go-Batam. berita maraknya kaum lgbt di indonesia pasangan homoseksual tertangkap warga sedang mesum di indekos. thttps://go-batam.co/berita-maraknyakaum-lgbt-di-indonesia-pasangan homoseksual tertangkap-warga-sedangmesum-di-indekost.html

Riau Online. (2015). 100 Cambuk bagi Pelaku Zina dan Homoseksual di Aceh. https://www.riauonline.co.id/nasional/read/2015/10/26/100-cambuk-bagipelaku-zina-dan-homoseksual-di-aceh

Wajibbaca.com. (2016). Heboh! Pasangan Gay Tulen Ini Punya Anak Kandung Kembar 3!. $\quad$ https://www.wajibbaca.com/2016/08/heboh-pasangan-gay-tulen-inipunya-anak.html 